\title{
Fabrication of third generation Al-Li alloy by friction stir welding: a review
}

\author{
MD PARWEZ ALAM* and A N SINHA \\ Mechanical Engineering department, National Institute of Technology Patna, Ashok Rajpath, Patna 800005, \\ India \\ e-mail: parwez.me13@nitp.ac.in
}

MS received 4 October 2018; revised 27 February 2019; accepted 15 April 2019; published online 30 May 2019

\begin{abstract}
Aerospace industry stimulates research for new materials to reduce the weight of it thereby reduction of fuel consumption. Aluminium-Lithium alloys have become a good alternative due to its inherent properties. Nevertheless, joining of these materials by traditional welding is difficult. Friction stir welding process considered as an ideal joining process for these materials due to low heat input. This paper reviews the fabrication of the latest generation of Al-Li alloy by friction stir welding. In addition, it also presents and discusses the effect of process parameters on microstructure, mechanical properties and precipitate distribution in friction stir welded joint of Al-Li alloy.
\end{abstract}

Keywords. Friction stir welding; aluminium-lithium alloy; heat generation; mechanical properties; precipitates.

\section{Introduction}

The Aluminium-Lithium (Al-Li) alloys have become the preferred material for spacecraft, aircraft, military and commercial applications because of their outstanding properties [1, 2]. High elastic modulus, high specific strength, rigidity, low density, excellent corrosion resistance, super-plasticity and fracture toughness even at cryogenic temperatures, enhanced resistance to high cycle fatigue are some of the properties [3-5]. Lithium is wellknown as the lightest metal $\left(0.534 \mathrm{~g} / \mathrm{cm}^{3}\right)$ and well soluble in Aluminium [6]. Addition of each 1 weight \% Lithium into Aluminium the density of Aluminium alloy reduces by $3 \%$ and elastic modulus of Aluminium alloy increased by $6 \%$ [7]. So, it is considered as an ideal structural material.

$\mathrm{Al}-\mathrm{Li}$ alloy has been classified into three generations according to their invention. Table 1 shows all the three generations of Al-Li alloys and developers. The first generation of $\mathrm{Al}-\mathrm{Li}$ alloys reported after the invention of AA2020 in 1958. It had low weight and higher modulus than the conventional aluminium alloy. However, these alloys had been withdrawn from commercial production in the 1960s due to production problem and brittleness [8]. In another work, the Soviet Union developed 01420 and $01421 \mathrm{Al}-\mathrm{Li}$ alloy and applied in aircraft and liquid oxygen tank. The production of Al-Li alloys in the Soviet Union was also stopped due to confrontation with the United States. Research on Aluminium-Lithium alloy again started

*For correspondence in the early 1980s due to oil crisis. Scientists and engineers looked for light materials to reduce fuel consumption and introduced the second generation of Al-Li alloys. These alloys contained less than 3\% copper and 1.9-2.7\% lithium which results $10 \%$ lower density and $25 \%$ higher specific stiffness than 2xxx and 7xxx series alloys [9]. It was mainly applied in the secondary structure of aircraft [8]. However, these alloys still suffered from low fracture toughness, corrosion, anisotropic mechanical properties and did not get wide use in the aircraft industry $[7,10]$. The need for high strength and low weight material produced the third generation of Al-Li alloy. The latest generation of Al-Li alloys was improved to overcome the shortcomings of the previous generation [9]. It contains lower amounts of Lithium $(<2 \%)$ [11-13].

The property evolution over the different Al-Li generations has been reviewed by Abd et al [14]. The mechanical and physical properties of the third generation $\mathrm{Al}-\mathrm{Li}$ alloy can fulfill the requirement of the future aircraft and space craft due to its low weight, performance enhancement and less inspection and maintenance [15]. Possible use of third generation Al-Li alloy is demonstrated in figure 1.

Joining of these materials by the traditional fusion welding process is very difficult [9]. Weld cracking, weld porosity and the loss of alloying element are some causes which are responsible for reducing the strength of welded joints [16-18]. Friction stir welding (FSW) is considered to be suitable for joining of these alloys [19, 20]. It was invented in 1991 by Wayne Thomas and his colleagues of The Welding Institute (TWI) at Cambridge, U.K. [21]. The 
Table 1. Chemical composition of Al-Li in Wt.\% alloy, density and developers $[1,14,36]$.

\begin{tabular}{|c|c|c|c|c|c|c|c|c|c|c|c|}
\hline Grade & $\mathrm{Li}$ & $\mathrm{Cu}$ & $\mathrm{Mg}$ & $\mathrm{Zr}$ & $\mathrm{Zn}$ & $\mathrm{Ag}$ & $\mathrm{Mn}$ & $\mathrm{Sc}$ & Al bal. & Density & Developers and year \\
\hline \multicolumn{12}{|c|}{ First generation } \\
\hline 2020 & 1.2 & 4.5 & & & & & 0.5 & & & 2.71 & Alcoa, 1958 \\
\hline 01420 & 2.1 & & 5.2 & 0.11 & & & & & & 2.47 & Soviet, 1965 \\
\hline 01421 & 2.1 & & 5.2 & 0.11 & & & & 0.17 & & 2.47 & Soviet, 1965 \\
\hline \multicolumn{12}{|c|}{ Second generation ( $\mathrm{Li} \geq 2$ wt. \%) } \\
\hline 2090 & 2.1 & 2.7 & & 0.11 & & & & & & 2.59 & Alcoa, 1984 \\
\hline 2091 & 2.0 & 2.0 & 1.3 & 0.11 & & & & & & 2.58 & Pechiney, 1985 \\
\hline 8090 & 2.4 & 1.2 & 0.8 & 0.11 & & & & & & 2.54 & EAA, 1984 \\
\hline 01430 & 1.7 & 1.6 & 2.7 & 0.11 & & & & 0.17 & & 2.57 & Soviet, 1985 \\
\hline 01440 & 2.4 & 1.5 & 0.8 & 0.11 & & & & & & 2.55 & Soviet, 1985 \\
\hline 1441 & 1.95 & 1.65 & 0.9 & 0.11 & & & & & & 2.59 & Soviet, 1985 \\
\hline 1450 & 2.1 & 2.9 & & 0.11 & & & & & & 2.60 & Soviet, 1985 \\
\hline 01460 & 2.25 & 2.9 & & 0.11 & & & & & & 2.60 & Soviet, 1985 \\
\hline \multicolumn{12}{|c|}{ Third generation $(\mathrm{Li}<2$ wt.\%) } \\
\hline 2195 & 1.0 & 4 & 0.4 & 0.11 & 0.4 & & & & & 2.71 & $\begin{array}{c}\text { LM/Reynolds, } \\
1992\end{array}$ \\
\hline 2196 & 1.75 & 2.9 & 0.5 & 0.11 & 0.35 & 0.4 & 0.35 & & & 2.63 & $\begin{array}{c}\text { LM/Reynolds } \\
2000\end{array}$ \\
\hline 2297 & 1.4 & 2.8 & 0.25 & 0.11 & 0.5 & & 0.3 & & & 2.65 & LM/Reynolds, 1997 \\
\hline 2397 & 1.4 & 2.8 & 0.25 & 0.11 & 0.10 & & 0.3 & & & 2.65 & Alcoa, 1993 \\
\hline 2098 & 1.05 & 3.5 & 0.53 & 0.11 & 0.35 & 0.43 & 0.35 & & & 2.70 & $\begin{array}{c}\text { Mc Cook Metals, } \\
2000\end{array}$ \\
\hline 2198 & 1.0 & 3.2 & 0.5 & 0.11 & 0.35 & 0.4 & 0.5 & & & 2.69 & Rey./McCook, 2005 \\
\hline 2099 & 1.8 & 2.7 & 0.3 & 0.09 & 0.7 & & 0.3 & & & 2.63 & Alcoa, 2003 \\
\hline 2199 & 1.6 & 2.6 & 0.2 & 0.09 & 0.6 & & 0.3 & & & 2.64 & Alcoa, 2005 \\
\hline 2050 & 1.0 & 3.6 & 0.4 & 0.11 & 0.25 & 0.4 & 0.35 & & & 2.70 & Pechiney, 2004 \\
\hline 2296 & 1.6 & 2.45 & 0.6 & 0.11 & 0.25 & 0.43 & 0.35 & & & 2.63 & Alcan, 2010 \\
\hline 2060 & 0.75 & 3.95 & 0.85 & 0.11 & 0.4 & 0.25 & 0.3 & & & 2.72 & Alcoa, 2011 \\
\hline 2055 & 1.15 & 3.7 & 0.4 & 0.11 & 0.5 & 0.4 & 0.3 & & & 2.70 & Alcoa, 2012 \\
\hline 2065 & 1.2 & 4.2 & 0.5 & 0.11 & 0.2 & 0.30 & 0.4 & & & 2.70 & Constellium, 2012 \\
\hline 2076 & 1.5 & 2.35 & 0.5 & 0.11 & 0.30 & 0.28 & 0.33 & & & 2.64 & Constellium, 2012 \\
\hline
\end{tabular}

FSW process joins the materials below the melting point of the concerned material. In this welding, there is no requirement of filler material. It is also free from fumes, arc flash, spatter, pollution and some defects which are associated with the most of the conventional welding processes [22, 23]. Figure 2 shows a schematic diagram of friction stir welding.

Heat generation and distribution are the fundamental phenomena of FSW. There are several process parameters responsible for heat generation during FSW. Rotational speed, Welding speed, force, plunge depth plunge speed, shoulder profile, shoulder size, probe diameter, probe length, tilt angle and material properties of backing plate are major process parameters. All these make a synergetic effect during the welding. Embedded thermocouple [24, 25] and infrared camera technique [26] is the basic tool by which temperature is measured during FSW. But temperature measurement in the stir zone is difficult due to stirring of material [27]. Many researchers proposed numerical and analytical heat flow model of friction stir welding to predict temperature [28-30]. Heat generation can be controlled by adjusting process parameters in friction stir welding [31].
Shi and $\mathrm{Wu}$ [32] observed that the total heat generation increases continuously during plunging and reaches its maximum value when the tool shoulder touches the top surface of the plate. In dwell period, the rotating tool holds for few seconds to achieve sufficient heat. It makes easier for the tool in traverse movement [33]. Due to insufficient heat, either the rotating material will unable to fill the gap behind the tool [34] or will break the tool [35].

A significant amount of work has been conducted in the past years to understand the effect of rotational speed and welding speed in friction stir welding [37-40]. Arbegast et al [41] considered rotational speed and welding speed are strong function of maximum temperature and rate of heat input, respectively, and they proposed pseudo heat index which is given by Eq. (1)

$$
\frac{T}{T_{m}}=K\left(\frac{\omega^{2}}{v \times 10^{4}}\right)^{\alpha}
$$

where the range of $\mathrm{K}$ and $\alpha$ is 0.65 to 0.75 and 0.04 to 0.06 , respectively and $\mathrm{T}_{m}\left({ }^{\circ} \mathrm{C}\right)$ is the melting point of the alloy. Rao et al [42] also demonstrated that the joint quality is 


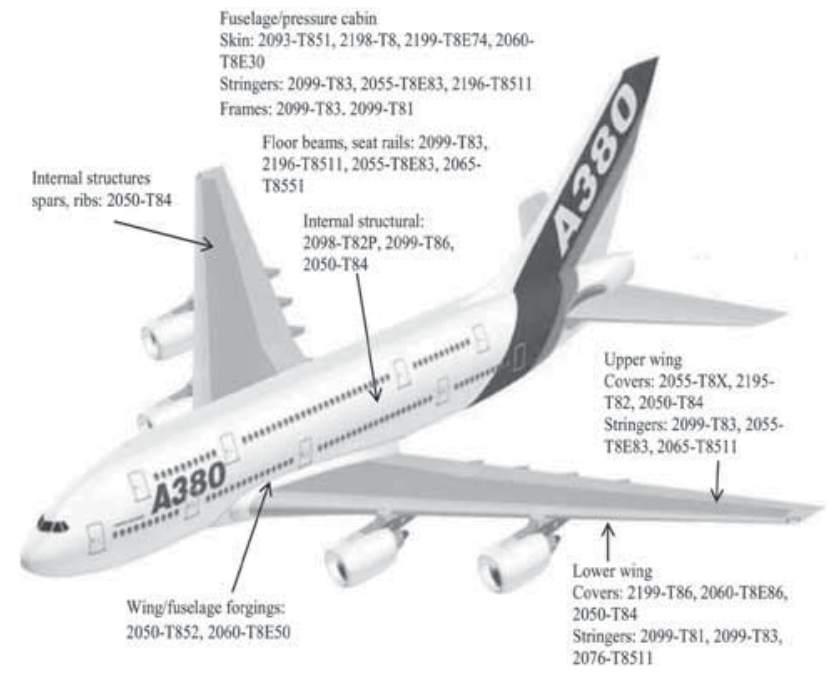

Figure 1. Proposed application of the third generation of Al-Li alloy [15].

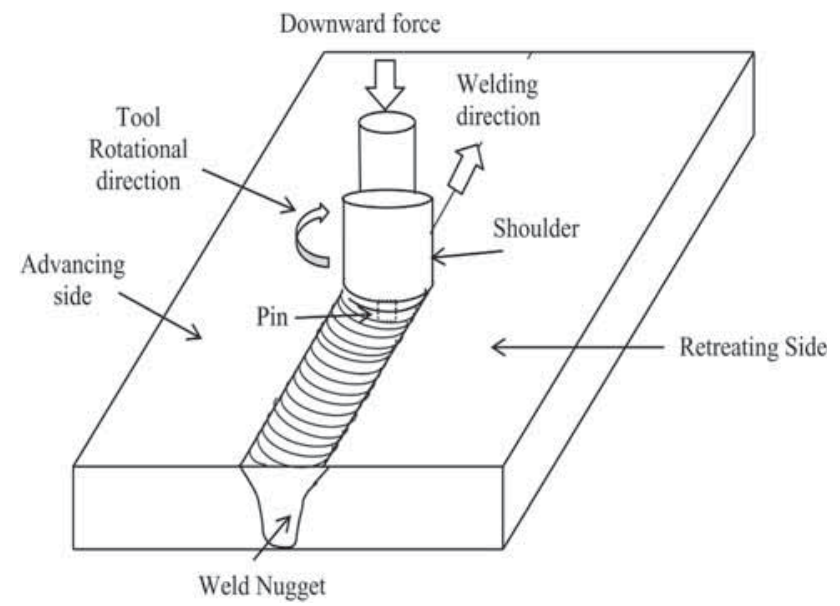

Figure 2. Schematic diagram of friction stir welding.

determined largely by the ratio of rotational speed to welding speed $(\omega / v)$. Mao et al [43] applied different rotational and welding speed and found the maximum tensile strength of the friction stir welded joint of $\mathrm{Al}-\mathrm{Li}$ alloy 2060 was $495 \mathrm{MPa}$ at $1180 \mathrm{rpm}$ and $118 \mathrm{~mm} / \mathrm{min}$.

Apart from this, tool design is one of the most important factors for successful welding. It is intimate contact with the workpiece during friction stir welding and performs many functions such as heat generation, material mixing, creating forging pressure, dispersing oxide layers, containing material within the joint and preventing from defects [23]. Numerous studies on tool design have been reported in the last few years. It has been concluded from previous studies that shoulder and tool pin are the key factor of heat generation, material mixing in the welding and determines the mechanical properties of welded joints [44-49]. It has been observed that flat, scroll and concave

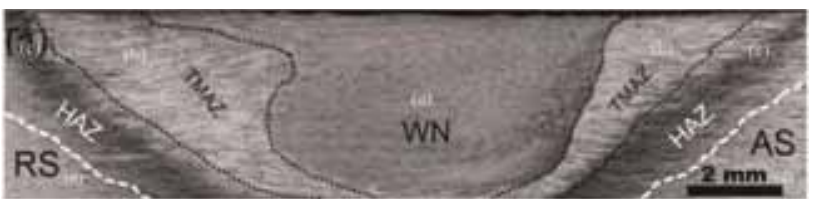

Figure 3. Macrostructural view of friction stir welded joint of AA2199: (a) SZ, (b) TMAZ, (c) HAZ and (d) BM [60].

feature of shoulder and frustrum shapped (truncated cone) with threaded, tapered triflat, threaded and cylindrical pin were applied in the joining of Al-Li alloy [50-56] Pin-less tool is also applied in the joining of thin sheet of $\mathrm{Al}-\mathrm{Li}$ alloys [57].

Cross section of the welded zone can be classified into four zones. They are; (a) Stir zone (SZ), (b) Thermomechanically affected zone, (c) Heat affected zone and (d) Base material. Details of microstructural evolution has been described in the next section. This paper reviews the microstructural evolution, tensile strength, fracture behaviour and precipitate distribution in friction stir welded joint of Al-Li alloy.

\section{Microstructural evolution}

According to the microstructural characterization of grains, friction stir welding is classified into four zones. They are: (a) stir zone (SZ), (b) thermomechanically affected zone (TMAZ), (c) heat affected zone (HAZ) and (d) base material (BM). The microstructures of these zones are shown in figure 3. The features of these four zones are different in the sense of grain size and grain shape, orientation and precipitate distribution [58]. Properties of any welded joint depend on microstructure which is governed by the thermal cycles [59].

Stir zone is the region through which the FSW tool passes. Due to vigorous plastic deformation and friction, temperature rises up to $95 \%$ of melting temperature of concerning material [34, 61]. This temperature is sufficient for recrystallization and forms fine equiaxed grains. Zhang et al [40] investigated grain morphology of friction stir welded joint of AL-Li alloy 2198 T8 in SZ and TMAZ and observed that microstructure of these zone changes from fine equiaxed grain and lathy bent grain to coarse columnar in as-welded condition to PWHT. Jata and Semiatin [62] established the mechanism of microstructure evolution in the stir zone of Al-Li alloy. The width and depth of the stir zone associated with the weld are nearly the same as the diameter and height of the tool pin [63-65]. Crown side experienced more heat than that of the bottom side due to contact with tool shoulder. Consequently, weld nugget is wider on the crown side than that of the bottom side $[50,66]$ and it looks like basin shape [67]. Ma and $\mathrm{Li}$ [51, 52] employed different $\omega / v$ in their experiment and reported that as the value of $\omega / v$ increases from 2 to 4 , the 


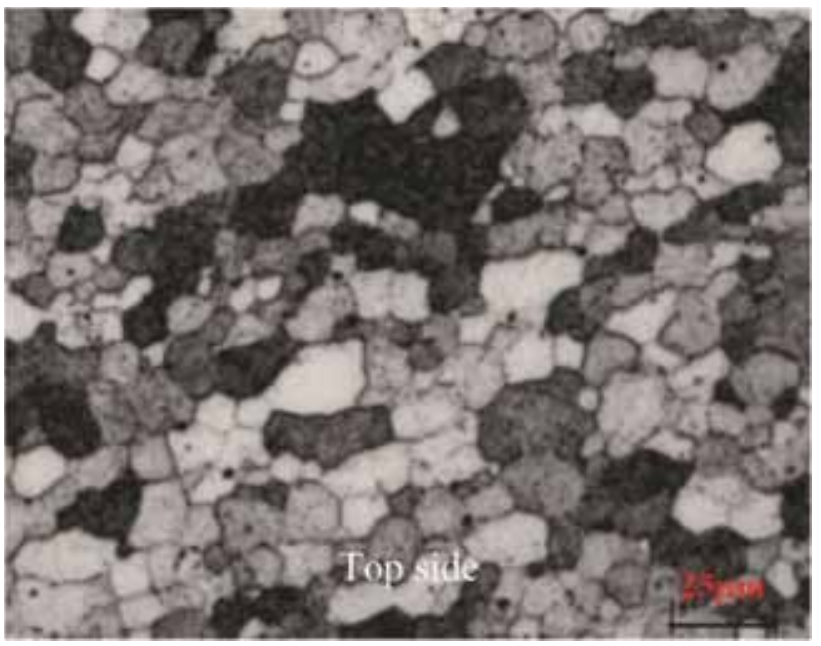

Figure 4. Grain sizes at the top side of friction stir weld [66].

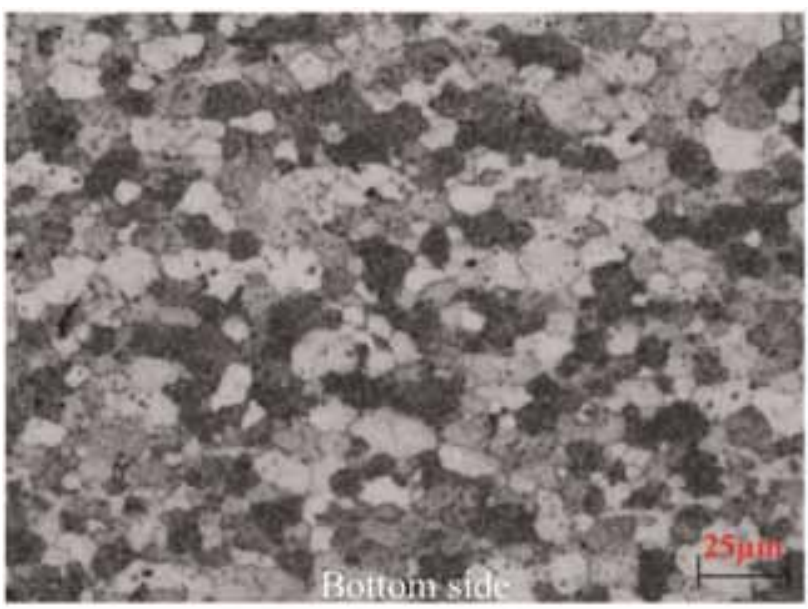

Figure 5. Grain sizes at the bottom side of friction stir weld [66].

shape of stir zone changes and area increased. Dhondt et al [68] analyzed the stir zone of AA2050 along thickness and found that the grain size decreases $17 \mu \mathrm{m}$ to $4 \mu \mathrm{m}$ from weld surface to bottom surface. Inhomogeneous grain size in stir zone of $\mathrm{Al}-\mathrm{Li}$ alloy is similar finding as the previous one [69]. It can also be noted from figures 4 and 5 that the grains on the top side are relatively larger compared to the bottom grains. This is due to temperature difference and effective strain rate in the stir zone. Benavides et al [70] correlated the grain size by the grain growth relations. It is represented by Eq. (2)

$$
\mathrm{d}^{2}-\mathrm{d}_{\mathrm{i}}^{2}=\operatorname{At}^{\mathrm{n}} \exp \left(-\frac{Q}{R T}\right)
$$

where $\mathrm{d}$ and $\mathrm{d}_{i}$ is the instantaneous and initial recrystallized grain size, respectively, $\mathrm{A}$ and $\mathrm{n}$ are constant, $\mathrm{Q}$ is the corresponding activation energy for grain growth, $t$ is the time, $\mathrm{R}$ is the gas constant and $\mathrm{T}$ is the absolute temperature. $\mathrm{T}$ is proportional to the amount of the heat input, $\mathrm{d}_{i}$ is assumed to be invariable.

Tao et al [71] found inhomogeneous stir zone during FSW and classified the SZ in three sub-zones as shoulder affected zone, pin affected zone and transition between them.

To avoid this inhomogeneity bobbin tool were used by Wang [72] while, Avettand et al [73] applied stationary shoulder friction stir welding (SSFSW) and found homogeneous stir zone. Threadgill et al [59] assumed that the FSW process act as an extrusion process. Rotating tool heats and softens the material around the tool and extruded from ahead of the tool. This material is deposited behind the tool and form semicircular shape, which is termed as onion ring. Chu et al [74] explained that the onion ring pattern is due to the geometric effect of the stirred material. The distance of consecutive pattern is equal to the distance of forwarding motion of the tool in one rotation $[75,76]$. TMAZ is a transition zone between stir zone and heat affected zone. This zone experiences both deformation and heating during FSW processing, but the temperature in this zone is not sufficient for recrystallization. The grains in the TMAZ were distorted and tended to orient along the flow pattern, and they explained that it is due to shear deformation induced by rotating tool [53, 77]. Rao et al [42] observed sharp transition between TMAZ and stir zone on the advancing side and much more diffuse in the retreating side.

In HAZ, grains influence only due to heat and the mechanical properties and microstructure were affected. In this zone, grains are similar to the base metal but smaller in size than that of base metal. Chen et al [54] reported that the width of TMAZ and the HAZ were wider on the retreating side, and they also explained that this was due to the accumulation of plastic metal on the retreating side.

\section{Properties}

\subsection{Microhardness}

The hardness test of any material gives an indication of resistance to abrasions. Microhardness of the friction stir welded joint is varying with microstructural zone and thickness of joint due to inhomogeneous heat distributions. Mariana et al [78] found asymmetric microhardness value in advancing side and retreating side. Ma et al [79] experimentally found that the hardness value of top, middle and bottom are $140 \mathrm{Hv}, 135 \mathrm{Hv}$, and $122 \mathrm{Hv}$, respectively. In table 2 characteristics of microhardness profile, grain size in stir zone and fracture location of welded plate is summarized. It has noted that the microhardness value is lower in HAZ and TMAZ than that of base metal and hardness profile was found as U shape. Sidhar et al [55] observed hardness of weld nugget slightly enhanced by applying PWHT. After PWHT hardness of joint increases 
Table 2. Highlights of microhardness distribution, joint efficiency and fracture location of joint.

\begin{tabular}{|c|c|c|c|c|c|}
\hline $\begin{array}{l}\text { Materials and } \\
\text { Thickness }\end{array}$ & $\begin{array}{l}\text { Microhardness value and } \\
\text { profile }\end{array}$ & $\begin{array}{c}\text { Grain size in stir } \\
\text { zone }\end{array}$ & $\begin{array}{c}\text { Joint } \\
\text { efficiency }\end{array}$ & Fracture location & References \\
\hline AA $2198,2 \mathrm{~mm}$ & $\begin{array}{c}\mathrm{BM}=161 \mathrm{H}_{\mathrm{v}} \\
\mathrm{WNZ}=80 \mathrm{H}_{\mathrm{v}} \\
\text { Shape: } \mathrm{U}\end{array}$ & Not Available & $71 \%$ & WNZ & {$[52]$} \\
\hline AA2060 T8, $2 \mathrm{~mm}$ & $\begin{array}{c}\mathrm{BM}=160 \mathrm{H}_{\mathrm{v}}-170 \mathrm{H}_{\mathrm{v}} \\
\mathrm{TMAZ}=107.8 \mathrm{H}_{\mathrm{v}} \\
\mathrm{WNZ}=119 \mathrm{H}_{\mathrm{v}} \\
\text { Shape: } \mathrm{W}\end{array}$ & $7.9 \mu \mathrm{m}$ & $92.5 \%$ & WNZ & [43] \\
\hline 2060-T8, $2 \mathrm{~mm}$ & $\begin{array}{c}\mathrm{BM}=165 \mathrm{H}_{\mathrm{v}} \\
\mathrm{TMAZ}=120 \mathrm{H}_{\mathrm{v}} \\
\mathrm{WNZ}=\sim 132 \mathrm{H}_{\mathrm{v}} \\
\text { Shape: } \mathrm{W}\end{array}$ & $\sim 2.3 \mu \mathrm{m}$ & $81.77 \%$ & $\begin{array}{c}\text { Interface of WNZ and TMAZ } \\
\text { (AS) }\end{array}$ & {$[67]$} \\
\hline 2195-T8, $1 \mathrm{~mm}$ & $\begin{array}{c}\text { At } 1800 \mathrm{rpm} \\
\mathrm{HAZ1}=176.8 \mathrm{H}_{\mathrm{v}} \\
\mathrm{HAZ2}=102.8 \mathrm{H}_{\mathrm{v}} \\
\mathrm{WNZ}=110.7 \mathrm{H}_{\mathrm{v}}\end{array}$ & $1-2 \mu \mathrm{m}$ & $\sim 70 \%$ & $\begin{array}{c}\text { Interface of HAZ and TMAZ } \\
\text { (AS) }\end{array}$ & {$[85]$} \\
\hline $2195-\mathrm{T} 8,2.5 \mathrm{~mm}$ & $\begin{array}{c}\mathrm{BM}=180 \mathrm{H}_{\mathrm{v}} \\
\mathrm{HAZ}=100 \mathrm{H}_{\mathrm{v}} \\
\mathrm{WNZ}=100 \mathrm{H}_{\mathrm{v}} \\
\text { Shape: } \mathrm{U}\end{array}$ & Not Available & $65 \%$ & $\begin{array}{c}\text { Interface of WNZ and TMAZ } \\
\text { (RS) }\end{array}$ & {$[40]$} \\
\hline 2195-T8, $50 \mathrm{~mm}$ & $\begin{array}{c}\mathrm{BM}=185 \mathrm{Hv} \\
\mathrm{HAZ}=126.8 \mathrm{Hv} \\
\mathrm{TMAZ}=110 \mathrm{Hv} \\
\text { WNZ }=130 \mathrm{Hv} \\
\text { Shape: } \mathrm{W}\end{array}$ & $\begin{array}{l}\text { Bottom }=4 \mu \mathrm{m} \\
\text { Top }=11 \mu \mathrm{m}\end{array}$ & Not Available & Interface of HAZ and TMAZ & {$[77]$} \\
\hline 2198-T8, $1.8 \mathrm{~mm}$ & $\begin{array}{c}\mathrm{BM}=180 \mathrm{Hv}_{0.2} \\
\mathrm{HAZ}=\mathrm{NA} \\
\mathrm{TMAZ}=160-105 \text { Hv0.2 } \\
\text { WNZ }=90-100 \text { Hv0.2 } \\
\text { Shape: Basin } \\
\text { Shape }\end{array}$ & $4.6-6.4 \mu \mathrm{m}$ & $74.44 \%$ & Not Available & [86] \\
\hline AA2198 T851, $3.2 \mathrm{~mm}$ & $\begin{array}{c}\mathrm{BM}=144 \mathrm{Hv} \\
\mathrm{TMAZ}=85 \mathrm{Hv} \\
\mathrm{WNZ}=88 \mathrm{Hv} \\
\text { Shape: At } 400 \mathrm{rpm} \\
\mathrm{U}\end{array}$ & Not Available & $80 \%$ & HAZ & {$[72]$} \\
\hline AA2198-T8, $2 \mathrm{~mm}$ & $\begin{array}{c}\mathrm{BM}=170 \mathrm{Hv} \\
\mathrm{HAZ}=\mathrm{NA} \\
\mathrm{TMAZ}=110 \mathrm{Hv} \\
\text { WNZ }=120 \mathrm{Hv} \\
\text { Shape: } \mathrm{W}\end{array}$ & Not Available & $75 \%$ & Not Available & {$[87]$} \\
\hline 2060-T8, $2 \mathrm{~mm}$ & Not Available & $6.2 \mu \mathrm{m}$ & $83 \%$ & WNZ & [37] \\
\hline AA2195-T8, $8.1 \mathrm{~mm}$ & $\mathrm{BM}=180 \mathrm{Hv}$ & $5-10 \mu \mathrm{m}$ & $68.33 \%$ & $\begin{array}{c}\text { Interface of HAZ and TMAZ } \\
(\mathrm{RS})\end{array}$ & [88] \\
\hline 2050-T851, $15 \mathrm{~mm}$ & $\begin{array}{c}\mathrm{BM}=\sim 180 \mathrm{Hv} \\
\mathrm{TMAZ}=\sim 130 \mathrm{Hv} \\
\mathrm{WNZ}=\sim 140 \mathrm{Hv} \\
\text { Shape: } \mathrm{W}\end{array}$ & Not Available & $82.69 \%$ & Not Available & {$[63]$} \\
\hline AA $2099,40 \mathrm{~mm}$ & $\begin{aligned} & \mathrm{BM}=96 \mathrm{Hv} \\
& \mathrm{HAZ}=105 \mathrm{Hv} \\
& \mathrm{TMAZ}=\sim 90 \mathrm{Hv} \\
& \text { WNZ }=100 \mathrm{Hv} \\
& \text { Shape: } \mathrm{W}\end{aligned}$ & $5 \mu \mathrm{m}$ & Not Available & Not Available & [89] \\
\hline $2198-\mathrm{T} 851,3.1 \mathrm{~mm}$ & $\begin{array}{c}\mathrm{BM}=170 \mathrm{Hv}_{0.1} \\
\mathrm{HAZ}=120 \mathrm{Hv}_{0.1} \\
\mathrm{TMAZ}=60 \mathrm{Hv}_{0.1} \\
\mathrm{WNZ}=70 \mathrm{Hv}_{0.1} \\
\text { Shape: } \mathrm{W}\end{array}$ & Not Available & $78 \%$ & Not Available & {$[90]$} \\
\hline AA2199-T8E74, $5 \mathrm{~mm}$ & $\begin{array}{c}\mathrm{BM}=150 \mathrm{Hv} \\
\mathrm{TMAZ}=90 \mathrm{Hv} \\
\text { WNZ }=95 \mathrm{Hv} \\
\text { Shape: } \mathrm{U}\end{array}$ & $5 \mu \mathrm{m}$ & Not Available & Not Available & [91] \\
\hline
\end{tabular}


and formed as W shape [62, 80]. Since, Al-Li alloys belong to heat treatable family, after friction stir welding temperature in stir zone is sufficient to recover their strength [81]. Oertelt et al [82] found that the hardness in dynamically recrystallized zone decreased after post weld thermal cycling.

The hardness value of friction stir welded joint is adversely influenced by rotational and welding speed. The hardness value increases with increasing rotation speed or decreasing welding speed due to more exposure time. Zhang et al [40] applied different $\omega$ and $v$ combinations with the same ratio of $\omega / v$ and they found a similar stir zone and thermo-mechanical zone, but different width of the HAZ. Ma et al [51] observed that the microhardness decreases with the increase of $\omega / v$. Sato et al correlated the hardness of materials and grain size [83]. Modified HallPetch equation represents in Eq. (3)

$$
H_{v}=H_{0}+K_{H} d^{\frac{-1}{2}}
$$

Where $\mathrm{H}_{v}$ is the hardness value, $\mathrm{H}_{o}\left(\mathrm{H}_{v}\right)$ and $\mathrm{K}_{H}\left(\mathrm{H}_{v} \mu \mathrm{m}^{1 /}\right.$ ${ }^{2}$ ) are constant associated with the hardness measurements and $\mathrm{d}(\mu \mathrm{m})$ is grain size of the material. It reveals that the hardness of material increases if grain size decreased or nugget zone should be harder than the base material. But it is clearly shown in table 2 that the hardness of the nugget zone is lesser than the base material. It can be concluded that the hardness of welded joint avoids this law. Dhondt et al [68] explained that the hardness value in friction stir welded joint is primarily dependent on $T_{1}$ precipitates and grain size effect is of second order. Schneider et al [31] also observed that the mechanical properties of FSW are strongly dependent on the size and distribution of the strengthening precipitates and slightly depend on the grain size.

It attributed that the hardness of joints is related to the distribution of the strengthening precipitates [50, 54]. Similar results were found experimentally by Geuser et al [84] and they correlated the microhardness value of welded joint with volume fraction of $\mathrm{T} 1$ precipitates, which is shown in figure 6.

Therefore, the hardness of weld nugget is influenced by process parameter, peak temperature, thermal boundaries, PWHT and precipitate distribution [12].

\subsection{Tensile tests}

The tensile test has been an excellent tool to understand the strength of the weld as compared to that of the parent material. Defects; such as tunnelling, void, micro cracks and kissing bond reduce tensile strengths of friction stir welded joint. Adjustments to the down force, optimal process parameters of the tool, helped to mitigate these defects. It has observed that the tensile strength of friction stir welded joint increases by increasing rotational speed up to certain value then decrease [72, 92]. Chen et al [54] applied

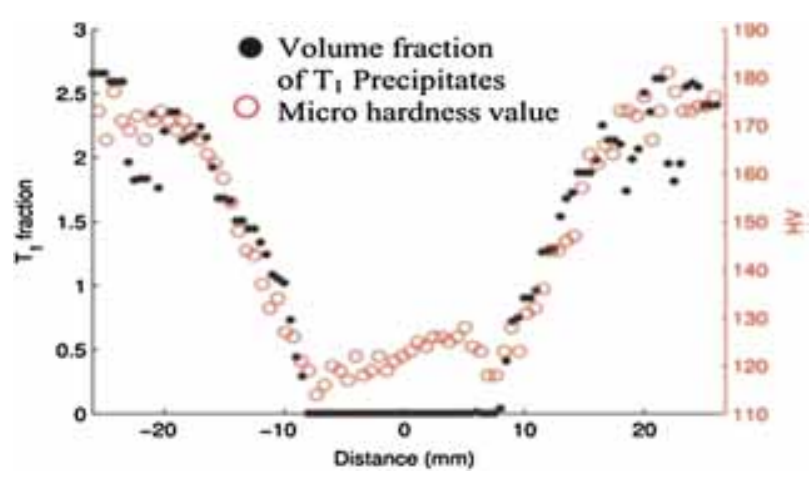

Figure 6. Distribution of $\mathrm{T} 1$ precipitates and microhardness in welded joint [84].

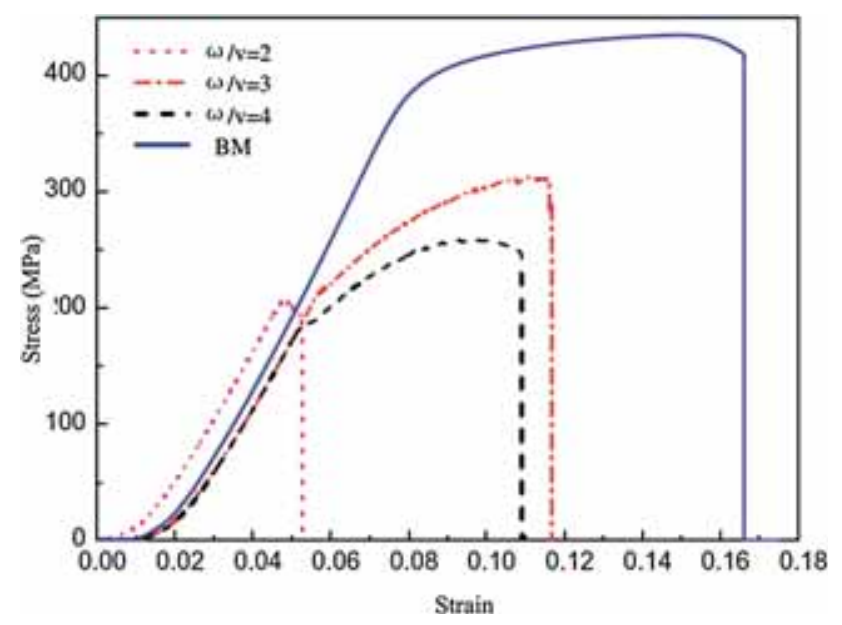

Figure 7. Effect of tensile strength at different $\omega / v$ [52].

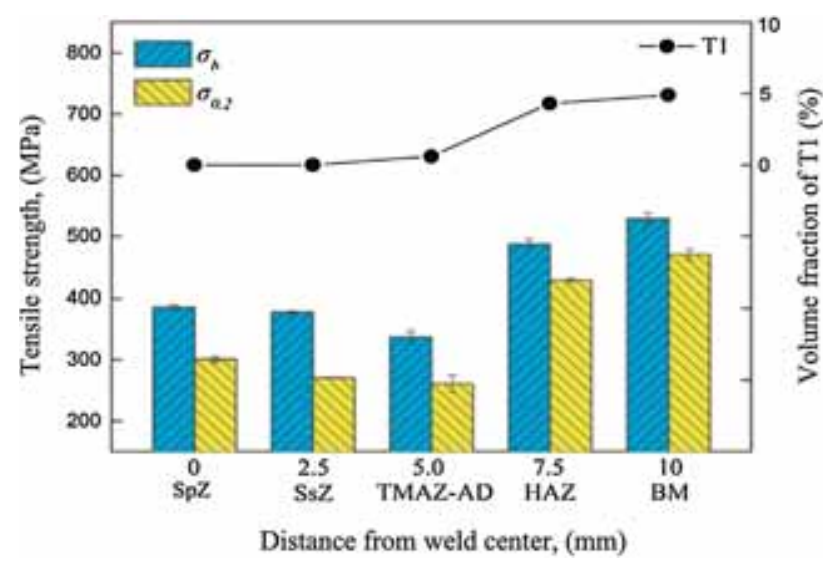

Figure 8. Correlation between volume fractions of T1 phase and tensile properties across weld [86].

four different rotational speeds from 600 to $1200 \mathrm{rpm}$ and found maximum tensile strength $350.8 \mathrm{MPa}$ at $800 \mathrm{rpm}$. They reported that the tensile strength reduces at low rotational speed due to insufficient plastic flow whereas; 
tensile strength reduces at high rotational speed due to excessive heat. Welding flaw was observed during high rotational speed and welding speed [42]. The grain size and softening zone increases due to the excessive heat input, consequently ductility and strength of joint reduced [65]. Mao et al [43] applied variable rotational speed and found insufficient material mixing at high rotational speed. They explained that the slipping condition of material changes into sticking condition and viscosity of the material dramatically decreased. Li et al [52] applied the different value of $\omega / v$ that is $2,3,4$ and remarked that greater tensile strength was found at $\omega / v=3$ which is shown in figure 7 . In addition, they also concluded that the tensile strength reduces due to the dissolution of strengthening phase and weak grain boundaries.

Kroninger et al [88] reported that the stress-strain curve of Al-Li alloys shows continuous yielding and break with necking whereas stress-strain curve of friction stir welded joint is totally different and directly break. Nelson et al [93] investigated the quench sensitivity of friction stir welded Al-Li alloy 2195 T8 and reported that the 2195 exhibits little or no change in mechanical properties. Nayan et al [94] observed that tensile and yield strength of Al-Li alloy dramatically increases at cryogenic temperature.

Ma et al [51] found strength of 2198 Al-Li alloys of FSW joints can be $71 \%$ of the base metal. They suggested two reasons for the lower strength than the base metal, (i) dissolving the precipitates and (ii) strong tendency to intergranular cracking of Al-Li alloys. Hatamleh et al [66] observed the lowest tensile properties across the weld region and explained original structure in that region was over-aged and there was not enough solute left in the material. Gao et al [86] found that the mechanical properties of friction stir welded joint have significant dependence on the volume fraction of $T_{1}$ phase across the welds, especially $\mathrm{T}_{1}$ distribution as shown in figure 8 .

\subsection{Fracture analysis}

Fracture mechanism of friction stir welded joint is governed by the different process parameters. It is not only determining the fracture location of the welded joint but also influences the manner of crack propagation. In general, failure occurs at the weakest region during the tensile test which exhibits the lowest hardness. Most of the joint fail in stir zone which is also a low hardness region in the aswelded condition. Microhardness distribution and fracture location were correlated by the previous researchers [95]. Based on the previous researcher it is concluded that nonAl-Li alloy fails only in low hardness zone [96-98] but AlLi alloys fail either in stir zone or low hardness zone [79, 88, 90]. Lin et al [89] experimentally observed that the tensile fractured of Al-Li alloy 2198-T8 occurred in stir zone instead of low hardness zone. They also investigated that the crack initiated from transition zone in stir zone and Omar et al [99] reported that the joint fails in heat affected zone near HAZ/TMAZ interface, i.e., the lowest hardness zone. Fracture patterns of joints were analyzed by several researchers by applying different process parameters. Mao et al [43] reported that fracture location shifted from HAZ to the SZ by increasing rotation speed or decreasing welding speed while $\mathrm{Li}$ et al [52] explore that fracture mode of Al-Li alloy changes from brittle to ductile fracture by increasing $\omega / v$.

In general, cracks initiated from volume defect or primary cracks in a defective welded joint. In contrast, fracture behaviour of sound welding is solely governed by microstructure and crack begins from the root side. Liu et al [92] observed cracks initiated from the root in stir zone and
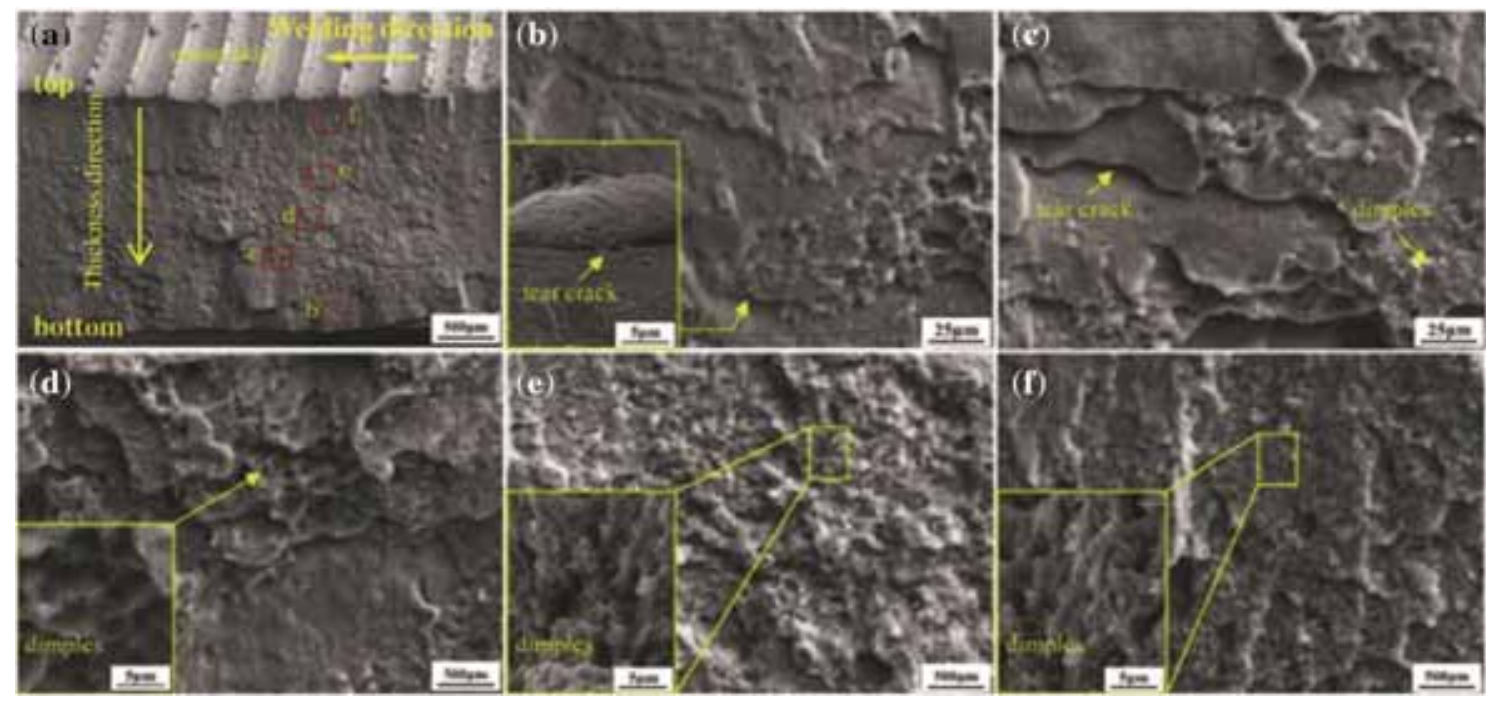

Figure 9. Fracture feature of the welded joint along thickness at rotation speed $800 \mathrm{rpm}$ [37]. 
they also reported that the fine dimple increases from root to the crown surface which shows surface nature change from brittle to ductile. It is also clearly shown in figure 9.

Chen et al [54] applied four different rotating speeds $600 \mathrm{rpm}, 800 \mathrm{rpm}, 1000 \mathrm{rpm}$ and $1200 \mathrm{rpm}$ with constant welding speed and observed two kinds of fracture mode. $45^{\circ}$ Shear fracture mode was found at $600 \mathrm{rpm}$ and wedgeshape fracture was observed at rest joint. Wang et al [72] applied bobbin tool FSW for homogeneous heat input, and they observed three types of fracture mode. At low rotation speed i.e., 400-600 rpm, fracture occurs in SZ and JLR play a significant role in joint fracture behavior. At $800 \mathrm{rpm}$ cracking start in HAZ region while at $1000 \mathrm{rpm}$ fracture location was found at the interface of TMAZ/SZ. Robe et al [100] performed dissimilar welding and found that the crack appears outside the weld nugget.

Chen et al [101] studied the effect of thermal exposure on Al-Li alloy of 2198, and they reported that the fracture mode changes from quasi-cleavage to ductile fracture by increasing exposure temperature. Al-Li alloy 2195 shows different fracture mechanism at different aging temperature. Ductile transgranular fracture with numerous dimples, mixed fracture with dimples and intergranular cracks and small dimple and mostly intergranular fracture mode was found at $135^{\circ} \mathrm{C}, 155^{\circ} \mathrm{C}$ and $170-200^{\circ} \mathrm{C}$ of aging temperature, respectively [102]. After age treatment fracture mode has been changed from ductile-brittle mixed fracture to brittle fracture. Before aging treatment cracks begin along dislocation free zone while it is completely changed after aging treatment and it is initiated along precipitate free zone [86]. Zhang et al [103] characterized $\mathrm{Al}-\mathrm{Li}$ alloy of 2198 and reported that the ductility of a material decreases if the aging temperature increased and fracture surface transforms from a typical dimple type to a dimple intergranular mixed type.

Zhang et al [40] studied friction stir welded joint of $2.5 \mathrm{~mm}$ thick $2195 \mathrm{~T} 8 \mathrm{Al}-\mathrm{Li}$ at the different condition, i.e., After welding, post weld heat treatments with the different solution and aging condition and concluded that joint strength increases after PWHT but ductility decreased and joint fails in SZ with the intergranular mode. Tayon et al [95] observed that precipitates distribution are homogenized by post welded solution heat treatment and aging temperature. They reported that the local texture is the more significant factor of fracture location than that of precipitates. Rao et al [4] observed fracture toughness of $\mathrm{Al}-\mathrm{Li}$ alloy increases at cryogenic temperature. This is due to using the cryogenic structural element such as liquid oxygen and liquid hydrogen tank [4].

\subsection{Precipitates distribution}

Al-Li alloy belongs to age hardened group which enables heat treatment [103]. During the welding, the temperature quickly rises, which accelerates the precipitate reaction in

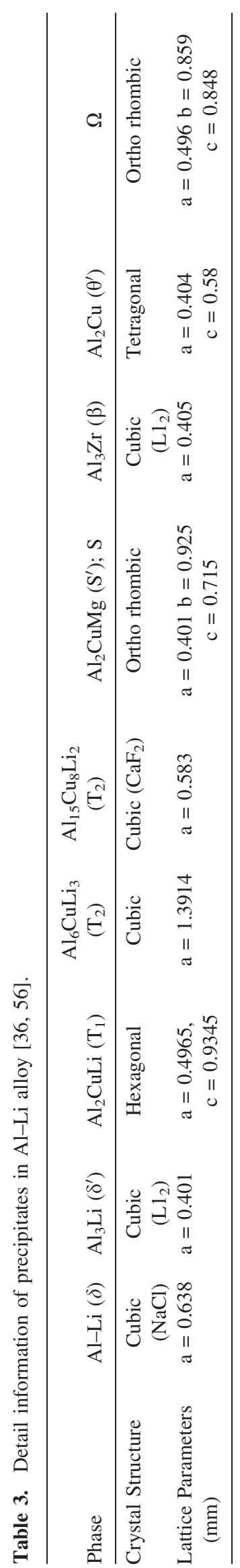




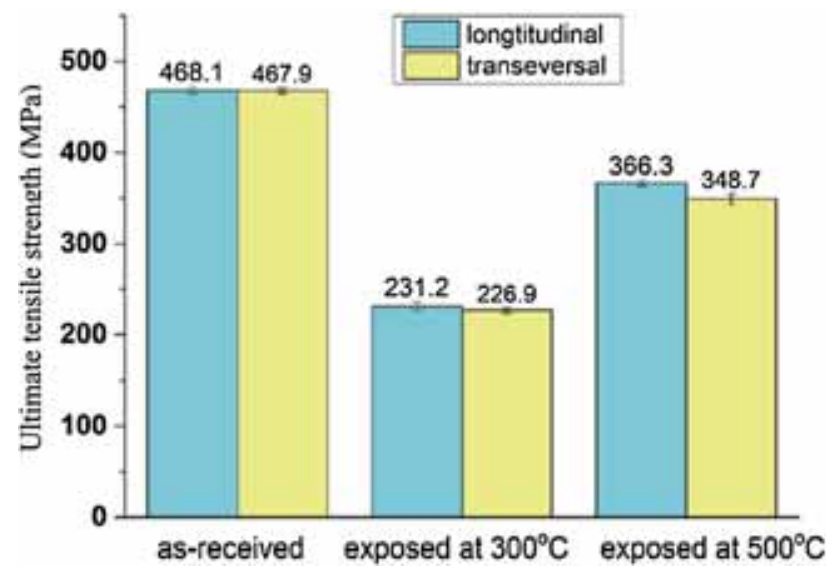

Figure 10. Strength of $\mathrm{Al}-\mathrm{Li}$ alloy at different temperature [101].

Al-Li alloy and also form a solid solution. Mechanical properties are significantly influenced by precipitates [104]. Differential scanning calorimetry (DSC) and Transmission electron microscopy (TEM) were used to evaluate volume fraction of precipitates, size and morphology in a different location of the weld joint in various PWHT [91]. $\mathrm{T}_{1}\left(\mathrm{Al}_{2}\right.$ $\mathrm{CuLi}), \theta^{\prime}\left(\mathrm{Al}_{2} \mathrm{Cu}\right), \beta^{\prime}\left(\mathrm{Al}_{3} \mathrm{Zr}\right), \delta^{\prime}\left(\mathrm{Al}_{3} \mathrm{Li}\right)$ and $\mathrm{S}^{\prime}\left(\mathrm{Al}_{2} \mathrm{CuMg}\right)$ are some precipitates which are contributing to the strength of age-hardened Al-Li alloy [105]. Table 3 shows the precipitate's shape and phase of Al-Li alloy.

Distributions of the precipitate particle in a different friction stir welded region are different [84]. It is due to the different temperature range in SZ, TMAZ and HAZ. Stir zone, which experiences the highest temperature than that of any other zone. In this zone, temperature lays more than $400^{\circ} \mathrm{C}$ which is sufficient to dissolve all strengthening precipitates [106]. High-temperature precipitates such as $\mathrm{T}_{2}, \mathrm{~T}_{B}, \theta^{\prime}, \theta^{\prime \prime}$ are formed at $320^{\circ} \mathrm{C}-380^{\circ} \mathrm{C}$ and dissolved at more than $430^{\circ} \mathrm{C}[31,107]$. Only $\theta^{\prime}$ and $\delta^{\prime}$ were found in the stir zone [2]. Needle-shaped precipitate $\mathrm{T}_{1}$ dissolves in stir zone. Precipitates $\mathrm{T}_{1}$ produced at $140^{\circ} \mathrm{C}-310^{\circ} \mathrm{C}$ and dissolves $400-470^{\circ} \mathrm{C}$ [31, 108, 109]. Qin et al [77] reported that the $\mathrm{T}_{1}$ phase in stir zone was transformed into $\delta^{\prime}$ $\left(\mathrm{Al}_{3} \mathrm{Li}\right)$ phases and it behaves like a major strengthening phase in stir zone. Similar finding was reported by Chen et al [101]. They reported that the mechanical properties of Al-Li alloy 2198 dramatically reduces strength when temperature exceeds $300^{\circ} \mathrm{C}$ due to the dissolution of strengthening phase $\mathrm{T}_{1}$ and $\theta^{\prime}$ phase whereas; it shows better mechanical properties at $400-500^{\circ} \mathrm{C}$ than that of $300^{\circ} \mathrm{C}$, due to precipitation of $\delta^{\prime}$ phase. Figure 10 represents the strength of Al-Li alloy at different temperature. $\mathrm{Li}$ et al [52] observed that the density and length of $\mathrm{T}_{1}$ phase in stir zone are relatively less than the base metal, and they explained that less joint strength in stir zone is due to more precipitate-free-zones (PFZ).

$200-400^{\circ} \mathrm{C}$ temperature observed in TMAZ and HAZ and it consists T1, $\theta^{\prime}, \delta^{\prime}$ precipitates [2, 77]. Shukla et al
[85] investigated the precipitation distribution of friction stir welded joint and reported that the $T_{1}$ phase in TMAZ exhibited partial dissolution whereas $\theta^{\prime}, \beta^{\prime}$ and $S^{\prime}$ phases exhibited complete dissolution in TMAZ. They also reported that the length and thickness of $T_{1}$ phase are slightly changed in this region. $\theta^{\prime}, \beta^{\prime}$ and $\delta^{\prime}$ which is lowtemperature precipitates produce at $25-50^{\circ} \mathrm{C}$ and dissolve 90- $120^{\circ} \mathrm{C}$ [110].

TMAZ could experience a combination of precipitate dissolution and coarsening, depending on the process parameters [34]. Since cooling rate during friction stir welding is so fast and it is not enough time to reprecipitate. However, these precipitates were replaced by different precipitates during cooling [97]. Reprecipitates may be achieved by applying proper thermal management including; process parameter and cooling rate. Kim et al [111] reported that the joint strength of the welded plate was improved by $\mathrm{T}_{1}$ phase, and they explained that it restricts the dissolution movement. With the increasing aging temperature, density and size of $\mathrm{T}_{1}$ precipitates also increases at grain boundary [101].

\section{Summary and future scope}

The latest generation of $\mathrm{Al}-\mathrm{Li}$ is found to be a suitable material for aerospace industries due to their excellent mechanical and metallurgical properties. FSW flourishes as better joining process of the latest generation of Al-Li alloy due to low heat input. This paper reviews the microstructural evolution, tensile strength, fracture behaviour and precipitate distribution in friction stir welded joint of $\mathrm{Al}-\mathrm{Li}$ alloy. The major findings from this review and future scope are as follows.

- It was observed that the variations of grain size, grain shape and distribution of precipitate in SZ, TMAZ, HAZ and BM. It was also observed that stir zone looks like basin shape. Shape and size of stir zone changes by changing the value of $\omega / \mathrm{v}$.

- Grain size and microhardness value decrease from top to the bottom. Microhardness value of the stir zone increases by applying post weld heat treatment.

- The strength of friction stir welded joint of $\mathrm{Al}-\mathrm{Li}$ alloys primarily depends on precipitates distribution rather than grain size.

- Crack propagation, fracture location and fracture behaviour changes by process parameter. Defect-free welding is solely governed by microstructure and crack begins from root side of welded joint. It was also observed that the Al-Li alloy fails either in stir zone or low hardness zone and the fracture mode of Al-Li alloy changes from brittle to ductile by increasing the value of $\omega / \mathrm{v}$.

- Major strengthening precipitates $\mathrm{T}_{1}\left(\mathrm{Al}_{2} \mathrm{CuLi}\right)$ dissolves in stir zone and $\delta^{\prime}\left(\mathrm{Al}_{3} \mathrm{Li}\right)$ behaves as a major strengthening phase in stir zone. 
- Numerous studies provided deep understanding of the various process parameters and their influence on the microstructure and mechanical properties of the welded joint. Despite these researches, complete understanding of thermal management during friction stir welding of Al-Li alloy is still lacking which requires more attention to explore. Thermal behavior between tool, workpiece and backing plate was not found which needs attention in future studies.

- Loss of strengthening precipitates in stir zone is an important issue of Al-Li alloy. More investigation is required to recover the precipitates by proper heat treatment.

$\begin{array}{ll}\text { Abbreviation } \\ \text { Al-Li } & \text { aluminium-Lithium } \\ \text { AS } & \text { advancing side } \\ \text { BM } & \text { base material } \\ \text { DSC } & \text { differential Scanning Calorimetry } \\ \text { FSW } & \text { friction stir welding } \\ \text { HAZ } & \text { heat affected zone } \\ \text { PFZ } & \text { precipitates free zone } \\ \text { PWHT } & \text { post weld heat treatment } \\ \text { RS } & \text { retreating side } \\ \text { SZ } & \text { stir zone } \\ \text { TMAZ } & \text { thermomechanicaly affected zone } \\ \text { WNZ } & \text { weld nugget zone }\end{array}$

\section{References}

[1] Rioja R J and Liu J 2012 The evolution of Al-Li base products for aerospace and space applications. Metall. Mater. Trans. A, 43: 3325-3337

[2] Cavaliere P, Cabibbo M, Panella F and Squillace A 2009 2198 Al-Li plates joined by friction stir welding: mechanical and microstructural behaviour. Mater. Des. 30(9): 3622-3631

[3] Decreus B, Deschamps A, De Geuser F, Donnadieu P, Sigli $\mathrm{C}$ and Weyland M 2013 The influence of $\mathrm{Cu} / \mathrm{Li}$ ratio on precipitation in $\mathrm{Al}-\mathrm{Cu}-\mathrm{Li}-\mathrm{x}$ alloys. Acta Mater. 61(6): 2207-2218

[4] Venkateswara Rao K and Ritchie R 1992 Fatigue in Aluminium Lithium Alloys. Int. Mater. Rev. 153-185

[5] Moreira P M G P, De Jesus A M P, De Figueiredo M A V, Windisch M, Sinnema G and De Castro P M S T 2012 Fatigue and fracture behaviour of friction stir welded aluminium-lithium 2195. Theor. Appl. Fract. Mech. 60(1): $1-9$

[6] Starke E A, Sanders T H and Palmer I G 1981 New approaches to alloy development in the Al-Li system. JOM, 33(8): 24-33

[7] Prasad N E, Gokhale A and Wanhill R J H (eds) 2013 Aluminum-lithium alloys: processing, properties, and applications. Butterworth-Heinemann
[8] Starke Jr. E A 2014 Historical development and present status of aluminum-lithium alloys In: Aluminum-lithium Alloys, Butterworth-Heinemann, pp. 3-26

[9] Dursun T and Soutis C 2014 Recent developments in advanced aircraft aluminium alloys. Mater. Des. 56: 862-871

[10] Krug Matthew E, David N Seidman and David C Dunand 2012 Creep properties and precipitate evolution in Al-Li alloys micro alloyed with Sc and Yb. Mater. Sci. Eng. A 550: $300-311$

[11] Lequeu P, Smith K P and A Daniélou 2010 Aluminumcopper-lithium alloy 2050 developed for medium to thick plate. J. Mater. Eng. Perform. 19: 841-847

[12] Mishra R S and Sidhar H 2017 Chapter 2-physical metallurgy of $2 \mathrm{XXX}$ aluminum alloys. In: H Sidhar, (editor). Friction stir welding of $2 X X X$ aluminum alloys including Al-Li alloys, Butterworth-Heinemann, pp. 15-36

[13] Suresh S, Vasudevan A K, Tosten M and Howell P R 1987 Microscopic and macroscopic aspects of fracture in lithium-containing aluminum alloys. Acta Metall. 35(1): 25-46

[14] El-Aty A A, Xu Y, Guo X, Zhang S, Ma Y and Chen D 2018 Strengthening mechanisms, deformation behavior, and anisotropic mechanical properties of Al-Li alloys: a review. J. Adv. Res. 10: 49-67

[15] Wanhill R J H and Bray G H 2014 Aerostructural design and its application to aluminum-lithium alloys. In: Aluminum-lithium alloys, Butterworth-Heinemann, pp. 27-58

[16] Xiao R and Xinyi Z 2014 Problems and issues in laser beam welding of aluminum-lithium alloys. J. Manuf. Process 16(2): 166-175

[17] Ram G J, Mitra T K, Raju M K and Sundaresan S 2000 Use of inoculants to refine weld solidification structure and improve weldability in type 2090 Al-Li alloy. Mater. Sci. Eng. A 276(1-2): 48-57

[18] Dhondt M, Aubert I, Saintier N and Olive J M 2014 Effects of microstructure and local mechanical fields on intergranular stress corrosion cracking of a friction stir welded aluminum-copper-lithium 2050 nugget. Corros. Sci. 86: $123-130$

[19] Le Jolu T, Morgeneyer T F, Denquin A and GourguesLorenzon AF 2015 Fatigue lifetime and tearing resistance of AA 2198 Al-Cu-Li alloy friction stir welds: effect of defects. Int. J. Fatigue. 70: 463-472

[20] Cavaliere P, Desantis A, Panella F and Squillace A 2009 Effect of anisotropy on fatigue properties of $2198 \mathrm{Al}-\mathrm{Li}$ plates joined by friction stir welding. Eng. Fail. Anal. 16: $1856-1865$

[21] Thomas W M 1991 Friction stir butt welding 1991 Inter. Pat. App. No. PCT/GB92/022-0.

[22] Ma Y E and Phil 2011 Residual stress effects and fatigue behavior of friction-stir-welded 2198-T8 Al-Li alloy joints. J. Aircr. 48(4): 1238-1244

[23] Gibson B T, Lammlein D H, Prater T J, Longhurst W R Cox, C D Ballun, M C Dharmaraj, K J Cook, G E and Strauss A M 2014 Friction stir welding: process, automation, and control. J. Manuf. Process. 16(1): 56-73

[24] Lee H-S, Yoon J-H, Yoo J-T and No K 2016 Friction stir welding process of aluminum-lithium alloy 2195. In: International conference on manufacturing engineering and materials, ICMEM2016, 6-10 June 2016, 
Novy Smokoves, Slovakia, volume 149, Procedia Engineering, pp. 62-66

[25] Chao Y J, Qi X and Tang W 2003 Heat transfer in friction stir welding-experimental and numerical studies $2003 \mathrm{~J}$. Manuf. Sci. Eng. 125(1): 138-145

[26] Dehelean D, Safta V, Cojocaru R, Hälker T and Ciuca C 2008 Monitoring the quality of friction stir welded joints by infrared thermography. Weld. World 52: 621-626.

[27] Alam M P and Sinha A N 2018 Nonlinear finite element simulation of friction stir welding of AA7075 T651 aluminium alloy. Int. J. Mech. Prod. Eng. Res. Dev. 8(5): 271-280

[28] Chao Y J and Qi X 1998 Thermal and thermo-mechanical modeling of friction stir welding of aluminum alloy 6061-T6. J. Mater. Process. Manuf. Sci. 7: 215-233

[29] Khandkar M Z H and Khan J A 2001 Thermal modeling of overlap friction stir welding for Al-alloys. J. Mater. Process. Manuf. Sci. 10: 91-105

[30] Frigaard $\varnothing$, Grong $\varnothing$ and Midling O T 2001 A process model for friction stir welding of age hardening aluminum alloys. Metall. Mater. Trans. A 32(5): 1189- 1200

[31] Schneider J A, Nunes A C, P Chen P S and Steele G 2005 TEM study of the FSW nugget in AA2195-T81. J. Mater. Sci. 40(16): 4341-4345

[32] Shi L and Wu C S 2017 Transient model of heat transfer and material flow at different stages of friction stir welding process. J. Manuf. Process. 25: 323-339

[33] Đurđanović M B, Mijajlović M M, Milčić D S and Stamenković D S 2009 Heat generation during friction stir welding process. Tribol. Ind. 31: 8-14

[34] Mishra R S and Ma Z Y 2005 Friction stir welding and processing. Mater. Sci. Eng. $R$ 50(1-2): 1-78

[35] Kang S-W, Jang B-S and Kim J-W 2014 A study on heatflow analysis of friction stir welding on a rotation affected zone. J. Mech. Sci. Technol. 28(9): 3873-3883

[36] Eswara P N and Ramachandran T R 2014 Phase diagrams and phase reactions in $\mathrm{Al}-\mathrm{Li}$ alloys. In: Aluminum-lithium alloys. Butterworth-Heinemann, pp. 61-97

[37] Liu H, Hu Y, Dou C and Sekulic D P 2017 An effect of the rotation speed on microstructure and mechanical properties of the friction stir welded 2060-T8 Al-Li alloy. Mater. Charact. 123: 9-19

[38] Lertora E and Gambaro C 2010 AA8090 Al-Li alloy FSW parameters to minimize defects and increase fatigue life. Int. J. Mater. Form. 3(1): 1003-1006

[39] Moshwan R, Yusof F, Hassan M A and Rahmat S M 2015 Effect of tool rotational speed on force generation, microstructure and mechanical properties of friction stir welded Al-Mg-Cr-Mn. Mater. Des. 66: 118-128

[40] Zhang J, Feng X S, Gao J S, Huang H, Ma Z Q and Guo L J 2018 Effects of welding parameters and post heat treatment on mechanical properties of friction stir welded AA 2195-T8 Al-Li alloy. J. Mater. Sci. Technol. 34(1): 219-227

[41] Arbegast W J and Hartley P J 1999 Friction stir weld technology development at lockheed martin michoud space system - an overview. ASM international, trends in welding research, pp. 541-546

[42] Rao J, Payton E J, Somsen C, Neuking K, Eggeler G, Kostka A and dos Santos JF2010 Where does the lithium go? A study of the precipitates in the stir zone of a friction stir weld in a Li-containing 2xxx Series Al Alloy. Adv. Eng. Mater. 12(4): 298-303

[43] Mao Y, Ke L, Liu F, Huang C, Chen Y and Liu Q 2015 Effect of welding parameters on microstructure and mechanical properties of friction stir welded joints of 2060 aluminum lithium alloy. Int. J. Adv. Manuf. Technol. 81(5-8): 1419-1431

[44] Zhang Y N, Cao X, Larose S and Wanjara P 2012 Review of tools for friction stir welding and processing. Can. Metall. $Q$ 51(3): 250-261

[45] Thomas W M, Johnson K I and Wiesner C S 2003 Friction stir welding-recent developments in tool and process technologies. Adv. Eng. Mater. 5(7): 485-490

[46] Rai R, De A, Bhadeshia H and DebRoy T 2011 Friction stir welding tools. Sci. Technol. Weld. Join. 16(4): 325-342

[47] Singh K V, Hamilton C and Dymek S 2010 Developing predictive tools for friction stir weld quality assessment. Sci. Technol. Weld. Join 15(2): 142-148

[48] Aissani M, Gachi S, Boubenider F and Benkedda Y 2010 Design and optimization of friction stir welding tool. Mater. Manuf. Process. 25(11): 1199-1205

[49] Elangovan K and Balasubramanian V 2008 Influences of tool pin profile and welding speed on the formation of friction stir processing zone in AA 2219 aluminium alloy. J. Mater. Process. Tech. 200(1-3): 163-175

[50] Malard B, Geuser F De and Deschamps A 2015 Microstructure distribution in an AA 2050 T34 friction stir weld and its evolution during post-welding heat treatment. Acta Mater. 101: 90-100

[51] Ma Y E, Xia Z C, Jiang R R and Li W 2013 Effect of welding parameters on mechanical and fatigue properties of friction stir welded $2198 \mathrm{~T} 8$ aluminum-lithium alloy joints. Eng. Fract. Mech. 114: 1-11

[52] Li W, Jiang R, Zhang Z and Ma Y E 2013 Effect of rotation speed to welding speed ratio on microstructure and mechanical behavior of friction stir welded aluminum-lithium alloy joints. Adv. Eng. Mater. 15(11): $1051-1058$

[53] Hatamleh O, Hill M, Forth S and Garcia D 2009 Fatigue crack growth performance of peened friction stir welded 2195 aluminum alloy joints at elevated and cryogenic temperatures. Mater. Sci. Eng. A 519(1-2): 61-69

[54] Chen H, Fu L and Liang P 2017 Microstructure, texture and mechanical properties of friction stir welded butt joints of 2A97 Al-Li alloy ultra-thin sheets. J. Alloys 692: 155-169

[55] Sidhar H, Mishra R S, Reynolds A P and Baumann J A 2017 Impact of thermal management on post weld heat treatment efficacy in friction stir welded 2050-T3 alloy. $J$. Alloys. Compd. 722: 330-338

[56] Fonda R W and J F Bingert 2006 Precipitation and grain refinement in a $2195 \mathrm{Al}$ friction stir weld. Metall. Mater. Trans. A 37(12): 3593-3604

[57] Chu Q, Li W Y, Yang X W, Shen J J, Vairis A, Feng W Y and Wang W B 2018 Microstructure and mechanical optimization of probeless friction stir spot welded joint of an Al-Li alloy. J. Mater. Sci. Technol. 34(10): 1739-1746

[58] Gao C, Ma Y, Tang L Z, Wang P and Zhang X 2017 Microstructural evolution and mechanical behavior of friction spot welded 2198-T8 Al-Li alloy during aging treatment. Mater. Des. 115: 224-230 
[59] Threadgill P L, A J Leonard H R Shercliff and P J Withers 2009 Friction stir welding of aluminium alloys. Int. Mater. Rev. 54(2): 49-93

[60] Sidhar H and Mishra R S 2016 Aging kinetics of friction stir welded $\mathrm{Al}-\mathrm{Cu}-\mathrm{Li}-\mathrm{Mg}-\mathrm{Ag}$ and $\mathrm{Al}-\mathrm{Cu}-\mathrm{Li}-\mathrm{Mg}$ alloys. Mater. Des. 110: 60-71

[61] Cam G and Mistikoglu S 2014 Recent develop- ments in friction stir welding of Al-alloys. J. Mater. Eng. Perform. 23(6): 1936-1953

[62] Jata K and Semiatin S 2000 Continuous dynamic recrystallization during friction stir welding of high strength aluminum alloys (No. AFRL-ML-WP-TP-2003-441), Air Force Research Lab Wright-Patterson AFB OH Materials and Manufacturing Directorate

[63] Pouget G and Anthony P Reynolds 2008 Residual stress and microstructure effects on fatigue crack growth in AA2050 friction stir welds. Int. J. Fatigue 30(3): 463-472

[64] John R, Jata K V and Sadananda K 2003 Residual stress effects on near-threshold fatigue crack growth in friction stir welds in aerospace alloys. Int. J. Fatigue 25(9-11): 939-948

[65] Avettand-Fenoel M N and Taillard R 2015 Heterogeneity of the nugget microstructure in a thick $2050 \mathrm{Al}$ frictionstirred weld. Metall. Mater. Trans. A 46(1): 300-314

[66] Hatamleh O 2008 Effects of peening on mechanical properties in friction stir welded 2195 aluminum alloy joints. Mater. Sci. Eng. A 492(1-2): 168-176

[67] Cai B, Z Q Zheng, D Q He, S C Li and H P Li 2015 Friction stir weld of $2060 \mathrm{Al}-\mathrm{Cu}-\mathrm{Li}$ alloy: Mi-crostructure and mechanical properties. J. Alloys Compd. 649: 19-27

[68] Dhondt M, Aubert I, Saintier N and Olive J M 2015 Mechanical behavior of periodical microstructure induced by friction stir welding on Al-Cu-Li 2050 alloy. Mater. Sci. Eng. A 644: 69-75

[69] Sutton M A Yang B Reynolds, A P and Taylor R 2002 Microstructural studies of friction stir welds in 2024-T3 aluminum. Mater. Sci. Eng. A 323(1-2): 160-166

[70] Benavides S, Li Y Murr, L Brown and McClure, J 1999 Low-temperature friction-stir welding of 2024 aluminum. Scr. Mater. 41(8): 809-815

[71] Tao Y, D R Ni, B L Xiao, Z Y Ma, W Wu, R X Zhang and Y S Zeng 2017 Origin of unusual fracture in stirred zone for friction stir welded 2198-T8 Al-Li alloy joints. Mater. Sci. Eng. A 693: 1-13

[72] Wang F F, W Y Li, J Shen, S Y Hu and J F dos Santos 2015 Effect of tool rotational speed on the microstructure and mechanical properties of bobbin tool friction stir welding of Al-Li alloy. Mater. Des. 86: 933-940

[73] Avettand-Fènoël M N and Taillard R 2016 Effect of a pre or post weld heat treatment on microstructure and mechanical properties of an AA 2050 weld obtained by SSFSW. Mater. Des. 89: 348-361

[74] Chu Q, Yang X W, Li W Y and Li Y B 2016 Microstructure and mechanical behaviour of pinless friction stir spot welded AA2198 joints. Sci. Technol. Weld. Join. 21(3): 164-170

[75] Dawood H I, Mohammed K S, Rahmat A and Uday M B 2015 The influence of the surface roughness on the microstructures and mechanical properties of 6061 aluminium alloy using friction stir welding. Surf. Coatings Technol. 270: 272-283
[76] Krishnan K N 2002 On the formation of onion rings in friction stir welds. Mater. Sci. Eng. A 327(2): 246- 251

[77] Qin H, Zhang H and Wu H 2015 The evolution of precipitation and microstructure in friction stir welded 2195-T8 Al-Li alloy. Mater. Sci. Eng. A 626: 322-329

[78] Milagre M X, Mogili N V, Donatus U, Giorjão R A, Terada M, Araujo J V S, Machado C S and Costa I 2018 On the microstructure characterization of the AA2098-T351 alloy welded by FSW. Mater. Charact. 140: 233-246

[79] Ma Y E, Staron P, Fischer T and Irving P E 2011 Size effects on residual stress and fatigue crack growth in friction stir welded 2195-T8 aluminium-part I: experiments. Int. J. Fatigue 33(11): 1417-1425

[80] Kamp N, Sullivan A and Robson J D 2007 Modelling of friction stir welding of 7xxx aluminium alloys. Mater. Sci. Eng. A 466(1-2): 246-255

[81] Dos Santos J F, Staron P, Fischer T, Robson J D, Kostka A, Colegrove P, Wang H, Hilgert J, Bergmann L, Hütsch L L and Huber $\mathrm{N}$ Understanding precipitate evolution during friction stir welding of $\mathrm{Al}-\mathrm{Zn}-\mathrm{Mg}-\mathrm{Cu}$ alloy through in-situ measurement coupled with simulation. Acta Mater. 148: 163-172

[82] Oertelt G Babu S S, David S A and Kenik E A 2001 Effect of thermal cycling on friction stir welds of 2195 aluminum alloy. Welding Journal 80(3): 71-79

[83] Sato Y S, Urata M, Kokawa H and Ikeda K 2003 HallPetch relationship in friction stir welds of equal channel angular-pressed aluminium alloys. Mater. Sci. Eng. A 354(1-2): 298-305

[84] De Geuser F, Malard B and Deschamps A 2014 Microstructure mapping of a friction stir welded AA 2050 Al-Li-Cu in the T8 state. Philos. Mag. 94(13): 1451-1462

[85] Shukla A K and Baeslack W A 2009 Study of process/structure/property relationships in friction stir welded thin sheet Al-Cu-Li alloy. Sci. Technol. Weld. Join. 14(4): 376-387

[86] Gao C, Zhu Z, Han J and Li H 2015 Correlation of microstructure and mechanical properties in friction stir welded 2198-T8 Al-Li alloy. Mater. Sci. Eng. A. 639: 489-499

[87] Ma Y E, Zhao Z, Liu B and Li W 2013 Mechanical properties and fatigue crack growth rates in friction stir welded nugget of 2198-T8 Al-Li alloy joints. Mater. Sci. Eng. A, 569: 41-47

[88] Kroninger H R and Reynolds A P 2002 R-curve behaviour of friction stir welds in aluminium-lithium alloy 2195. Fatigue Fract. Eng. Mater. Struct. 25(3): 283-290

[89] Lin Yi and Ziqiao Zheng 2017 Microstructural evolution of $2099 \mathrm{Al} \mathrm{Li}$ alloy during friction stir welding process. Mater. Charact. 123: 307-314

[90] Jolu T Le, Thilo F Morgeneyer and Anne-Françoise Gourgues-Lorenzon 2010 Effect of joint line remnant on fatigue lifetime of friction stir welded Al-Cu-Li alloy. Sci. Technol. Weld. Join 15(8): 694-698

[91] Steuwer A, Dumont M, Altenkirch J, Birosca S, Deschamps A, Prangnell P B and Withers P J 2011 A combined approach to microstructure mapping of an Al-Li AA2199 friction stir weld. Acta Mater. 59(8): 3002-3011

[92] Liu H, Hu Y, Dou C and Sekulic D P 2017 An effect of the rotation speed on microstructure and mechanical properties of the friction stir welded 2060-T8 Al-Li alloy. Mater. Charact. 123: 9-19 
[93] Nelson T W, Steel R J and Arbegast W J 2003 In situ thermal studies and post-weld mechanical properties of friction stir welds in age hardenable aluminium alloys. Sci. Technol. Weld. Join 8(4): 283-288

[94] Nayan N, Narayana Murty V V S, Jha A K, Pant B, Sharma S C, George K M and Sastry G V S 2014 Mechanical properties of aluminium-copper-lithium alloy AA2195 at cryogenic temperatures. Mater. Des. 58: 445-450

[95] Tayon W A, Domack M S, Hoffman E K and Hales S J 2013 Texture evolution within the thermo-mechanically affected zone of an Al-Li alloy 2195 friction stir weld. Metall. Mater. Trans. A, 44(11): 4906-4913

[96] Xu W, Liu J, Luan G and Dong C 2009 Microstructure and mechanical properties of friction stir welded joints in 2219-T6 aluminum alloy. Mater. Des. 30(9): 3460-3467

[97] Fonda R W and Bingert J F 2004 Microstructural evolution in the heat-affected zone of a friction stir weld. Metall. Mater. Trans. A 35(5): 1487-1499

[98] Sato Y S and Kokawa H 2001 Distribution of tensile property and microstructure in friction stir weld of 6063 aluminum. Metall. Mater. Trans. A 32(12): 3023-3031

[99] Hatamleh O 2009 A comprehensive investigation on the effects of laser and shot peening on fatigue crack growth in friction stir welded AA 2195 joints. Int. J. Fatigue 31(5): 974-988

[100] Robe H, Zedan Y, Chen J, Monajati H, Feulvarch E and Bocher P 2015 Microstructural and mechanical characterization of a dissimilar friction stir welded butt joint made of AA2024-T3 and AA2198-T3. Mater. Charact. 110: 242-251

[101] Chen B, Guo M F, Zheng J X, Zhang K Y, Fan Y, Zhou L Y, Li X L and Lu C 2016 The effect of thermal exposure on the microstructures and mechanical properties of $2198 \mathrm{Al}-$ Li Alloy. Adv. Eng. Mater. 18(7): 1225-1233

[102] Wang X H, Wang J H, Yue X and Gao Y 2015 Effect of aging treatment on the exfoliation corrosion and stress corrosion cracking behaviors of 2195 Al-Li alloy. Mater. Des. 67: 596-605

[103] Zhang S F, Zeng W D, Yang W H, Shi C L and Wang H J 2014 Ageing response of a Al-Cu-Li 2198 alloy. Mater. Des. 63: 368-374

[104] Deng Y, Bai J, Wu X, Huang G, Cao L and Huang L 2017 Investigation on formation mechanism of $\mathrm{T} 1$ precipitate in an Al-Cu-Li alloy. J. Alloys Compd. 723: 661-666

[105] Deschamps A, Decreus B, De Geuser F, Dorin T and Weyland M 2013 The influence of precipitation on plastic deformation of $\mathrm{Al}-\mathrm{Cu}-\mathrm{Li}$ alloys. Acta Mater. 61(11): 4010-4021

[106] Shukla A K and Baeslack W A III 2007 Study of microstructural evolution in friction-stir welded thin-sheet $\mathrm{Al}-\mathrm{Cu}-\mathrm{Li}$ alloy using transmission-electron microscopy. Scr. Mater. 56(6): 513-516

[107] Kumar K S, Brown S A and Pickens J R 1996 Microstructural evolution during aging of an $\mathrm{AlCu}-$ LiAgMgZr alloy. Acta Mater. 44(5): 1899-1915

[108] Dorin T, Deschamps A, De Geuser F, Lefebvre W and Sigli C 2014 Quantitative description of the T1 formation kinetics in an $\mathrm{Al}-\mathrm{Cu}-\mathrm{Li}$ alloy using differential scanning calorimetry, small-angle X-ray scattering and transmission electron microscopy. Philos. Mag. 94(10): 1012-1030

[109] Kumar K S and Heubaum, F H 1997 The effect of Li content on the natural aging response of Al-C-Li-Mg-Ag-Zr alloys. Acta Mater. 45(6): 2317-2327

[110] Chen P S and Stanton W P 1996 A new aging treatment for improving cryogenic toughness of the main structural alloy of the super lightweight tank, National Aeronautics and Space Administration. Marshall Space Flight Center

[111] Kim J H, Jeun J H, Chun H J, Lee Y R, Yoo J T, Yoon, J H and Lee H S 2016 Effect of precipitates on mechanical properties of AA2195. J. Alloys Compd. 669: 187-198 